\title{
SPEAKING SKILL THROUGH TASK BASED LEARNING IN ENGLISH FOREIGN LANGUAGE CLASSROOM
}

\author{
${ }^{\# 1}$ Nurul Afifah, ${ }^{* 2}$ Trisilia Devana \\ ${ }^{\# 1}$ English Lecturer, Training and education faculty, Universitas Baturaja, Indonesia \\ ${ }^{* 2}$ English Lecturer, Training and education faculty, Universitas Baturaja, Indonesia \\ Corresponding Email: nurulafifah122@gmail.com
}

\begin{abstract}
A B S T RA C T S
Speaking is one way to express ourselves when communicate. Most of students fail when they perform speaking skill. They faced problems in expressing themselves using in accurate, fluent and even simple sentences. Task based learning is an approach that need the completion of meaningful tasks. Task Based Learning focuses on the use of language for genuine in communication. This study used quasi experimental research. The sample of the study is Fourth Semester of English education study program of Baturaja University with the total sample 36 students. The data is conducted of two groups: one experimental group and one control group taught conventionally. Based on the data analysis the researcher concluded that task based learning was effective to improve the students' speaking skill in EFL Classroom. The result data from the mean score of posttest in experimental class was 49,11 and the mean score of posttest in control class was 51,88 . While, the value of sig. (2-tailed $)=0.000$ less than significant level $(\alpha=0.05)$, it meant that alternative hypothesis (Ha) was accepted and the null hypothesis (Ho) was rejected. The researcher concluded the result of posttest in experimental higher than the result of posttest in control class. It means that task based learning was significantly improve the students' speaking skill at fourth semester of English education study program of Baturaja University. Based on the finding on questionnaire, it could be described that almost the students gave positive response on the use of task based learning. The students strongly agree that task based learning help them enjoy in learning English and they also mostly agree that task based activities is a good way to improve English vocabulary.
\end{abstract}

\begin{tabular}{l}
\hline A R T I C L E I N F O \\
\hline Article History: \\
Received: October, 2020
\end{tabular}

Revised: November, 2020

Published: December, 2020

Keywords:

Speaking Skill,

Task based learning,

English Foreign Language,

How to cite: Afifah, N., \& Devana, T. (2020). Speaking Skill through Task Based Learning in English Foreign Language Classroom. Jo-ELT (Journal of English Language Teaching) Fakultas Pendidikan Bahasa \& Seni Prodi Pendidikan Bahasa Inggris IKIP, 7(2), 135-144. doi:https://doi.org/10.33394/jo-elt.v7i2.3109

\section{INTRODUCTION}

Speaking is of one of productive skills that must be mastered in learning foreign language. It will be good qualified people in the future if non-native speaker mastered English. According to Aleksandrzak, M (2011) stated that inside the circumstance of English Language Teaching in Indonesia as a foreign language (EFL), one of the objectives of English language teaching is the improvement of speaking skill that is oral skill as a product of learning.

There are some difficulties faced by the students in Indonesia to learn English. One of difficult thing that should be realized by the students and it was also as challenging when they learn English is speaking. It is because when they deliver speaking skill needs preparation from their psychological aspect such as they courage to convey their ideas and it's of course 
needs careful preparation to produce the target language (Malihah, N, 2010). Furthermore, Good speaking is characterized by some factors of the most prominent one is fluency, but many students are hesitant and often make long pauses when they are speaking. These situations lead them to 'social phobia, which is the fear that they will act in a humiliating way and that other people will judge them negatively (Cheong, K., et al, 2015). While According to Kayi, H. (2006) Speaking is the process of delivering verbal and non-verbal symbols in a variety of context through building and making the meaning". Speaking is very important to express our feeling, information, our emotion and our will orally. Speaking is also called active use of language. Someone who are able to use language properly its means that didn't' only known well about the theory but also known well how to use it. Speaking is different to other productive skill such as writing.

Furthermore, According to Brown, D, (2001) stated that Experts have proposed various aspects of speaking skills. There are four aspects of speaking skills namely fluency, accuracy, pronunciation, and vocabulary. The first aspect is related to fluency. Fluency as a signs person's level of communication proficiency, it is when the person able to speak quickly and few pauses and also speak automatically. (Jack, c Richards and Theodore S Rodges, 2001). The ability of speaking spontaneously is recognized as fluency. The second aspect is related to accuracy. According to Brown, D (2001) stated that accuracy is the ability to produce correct sentences using correct grammar and vocabulary in natural interaction. It means that accuracy is focused on the speaker the elements of phonology, grammar, and discourse in their spoken output. The accuracy in speaking can be provided by engagement in the context of daily life. The teacher should give the students communicative tasks and activities such as games, conversation, role play, debates, etc. Those kinds of activities can engage the learners in the natural interaction process whenever possible. The third aspect is related to pronunciation. Having a good pronunciation of the language can be helpful in a normal communication, particularly for intelligibility (Derwing, T. M. and Munro, M. J, 2005). The fourth aspect is related to vocabulary. Anyone will have little understanding in terms of listening; speaking, reading, and writing if anyone limited vocabulary. In

addition, based on Richards \& Rodges (2001) stated that students' lack of exposures, lack of confidence, lack of motivation, and lack of speaking skill knowledge are also several factors why students are difficult to comprehend and develop speaking skills. Based on the researcher preliminary observation the difficulties also experienced by English students at English education study program Baturaja University. It was describes most of the students reluctant and nervous perform speaking in front of the classroom. Most of students even don't have motivation to ask questions even to answer the teacher's questions. It's situation convey indirectly that students need more time to practice and get used themselves in the context of real communication to speak communicatively.

Based on the problem mention above, it's very necessary to use proper teaching technique. Task based learning is one of solution to fulfill demands as aforementioned particularly in providing optimal circumstance for EFL students to improve their speaking skill. Task based learning is a learner-centered approach; it has primary focus on the task completion, uses analytical approach and specifies learners' real-life communication needs. Furthermore, task based learning has an outline as a set of activities used by the learner for a communicative purpose in order to achieve an outcome (Willis, 1996). Task based learning is an approach in teaching speaking, the teacher ask the students to perform tasks that resemble authentic, "real-life" situations (Lemmolo, 2019). Furthermore, pavlenko, o stated that Task Based Learning is a learner-centered approach, Task based learning has primary focus on the task completion, uses analytical approach and specifies learners' real-life communication needs. 
The lesson is emphasized on the central task, the study about language determined by what happens when the students try to complete the task. The teacher in this activities is not decide what the target language will be studied (Frost, 2019). Furthermore, according to Zakime (2018) stated that Task Based Learning (TBL), or (Task-based language teaching (TBLT) is an approach in which learning revolves around the completion of meaningful tasks.

According to Ismail (2000) The TBT framework consists of three main phrases, provides 3 basic conditions for language learning: first, Pre-task (including topic and task) prepares learners to perform tasks in ways that promote acquisition. Second, Task cycle: offers learners the chance to use whatever language they already know in order to carry out the task and then to improve their language under the guidance from the teacher and the students prepare to plan their reports on the task that were given by the teacher. There are three components of task circle namely; First, Task its means that the learners are able to use the language that they have mastered, able to work in pairs and also in small groups simultaneously to realize the purpose of the task. Second, Planning means learners plan their reports effectively and maximize their learning opportunities. The third, report its means that the leaners are able to tell the class naturally about their findings. The last, Post-task stage: provides an opportunity for students to reflect on their task and encourages attention to form, in particular to problematic forms which demonstrate when learners have accomplished the task.

Based on the explanation above, the writer was interested in find out the effectiveness of task based learning in English Foreign Language.

\section{RESEARCH METHOD \\ Research Design}

According to Cohen, et al (2001) stated that quasi experimental design is a form of experimental research used extensively which involves one experimental group and one control group. Furthermore, this research is quasi experiment research.

In this research, the procedure to do the research different as usual, because all of steps in this research will be done through online way, it is because our country is experiencing pandemic covid-19 that can be contagious through air and droplet as a result it is very good for us use mask and do physical distancing. Furthermore, it is impossible to the researcher do the research face to face as usual. The first step the writer will select two classes as the participant of the study. Two classes will be determined as experimental group and control group. The first data (pre-test) scores will be collected from students' problem in learning process; in this case the students' are able to tell about social situations they faced during in our country experienced covid-19, they tell about situations in some place such as in traditional market, campus and social activities such as wedding ceremony etc. At this point for each student I took a note on a speaking rubric. After pre-test the students will be given a treatment by using task based learning approach. On the post test the students were score were taken after they performed the task based teaching. The research design could be seen Figure 1. 


\begin{tabular}{|lc|}
\hline \multicolumn{1}{|c|}{ X1 } & \multicolumn{1}{c|}{ X } \\
& 02 \\
& \\
Where: & \\
$01=$ Pre-test of experimental group \\
$02=$ Post-test of experimental group \\
$\mathrm{X}=$ Treatment \\
$03=$ Pre-test of control group \\
$04=$ Post-test of control group \\
\end{tabular}

Figure 1. Research Design

(Source: Cohen, et.al, 2005)

\section{Population and Sample}

Population of this study is all of the students of English students in semester IV at English education study program Baturaja University with the total 36 students. The writer used stratified random sampling (Fraenkel \& Wallen, 2009). The selection group or cluster of subject rather than individuals is known as cluster random sampling. The technique to get the subject are first, the writer collected the data from English students in semester IV then written and shook it off. For the first paper that comes out, decided it as an experimental group and the second paper as a control group. The experimental group 18 students and control group 18 students.

\section{Instruments}

The data in this research also were taken through online or daring. The data were collected by using questionnaire and speaking task. A questionnaire is used know the students perception on the use of task based learning in classroom. Meanwhile, there are two tests, pre-test and post-test. Pre -test will be conducted to know initial speaking skill of the students. Post-test will be given in order to check whether the task has effect or not toward the students speaking skill. Furthermore, reliability and validity of the instruments will be measured before they are administered to the students.

\section{Data Analysis}

The data analyzed using t-tests, normality test and homogeneity test. T-tests will be used to find out; the mean gain score of the experimental group and control group. The normality and homogeneity is intended to know the data is normally distribute or homogenous or not.

\section{RESEARCH FINDINGS AND DISCUSSION Research Finding}

The findings of the research first, the data of pre-test score in experimental group showed that the highest score of the pre-test was 76 while the lowest one was 40 . The mean of the scores was 59.29, the median was 65 and the mode was 40. Standard deviation of the data was 11,80. Second, the data of post-test scores in experimental group showed that the highest score of the pre-test was 800, while the lowest one was 55 . The mean of the scores was 69, 35, the median was 55 and the mode was 55. Standard deviation of the data was 7, 95. Third, the data of pre-test scores in control group showed that the highest score of the pre-test was 800 , while the lowest one was 55 . The mean of the scores was 69,35 , the 
median was 55 and the mode was 55. Standard deviation of the data was 7, 95. and the last, the data of post-test scores in control group showed that the highest score of the post-test was 65 , while the lowest one was 40 . The mean of the scores was 51,88 , the median was 55 and the mode was 55. Standard deviation of the data was 7, 12 .

The resume of data description was presented in Table 1.

Table 1

The resume of pretest and posttest score

\begin{tabular}{|l|c|c|c|c|}
\hline Group & $\begin{array}{c}\text { Pre-Test } \\
\text { Experimental } \\
\text { Group }\end{array}$ & $\begin{array}{c}\text { Post-Test } \\
\text { Experimental } \\
\text { Group }\end{array}$ & $\begin{array}{c}\text { Pre-Test } \\
\text { Control } \\
\text { Group }\end{array}$ & $\begin{array}{c}\text { Post-Test } \\
\text { Control } \\
\text { Group }\end{array}$ \\
\hline Mean & 59,29 & 49,11 & 69,35 & 51,88 \\
\hline Median & 65 & 45 & 70 & 55 \\
\hline Mode & 45 & 45 & 65 & 55 \\
\hline Highest & 76 & 62 & 80 & 65 \\
\hline Lowest & 40 & 35 & 55 & 40 \\
\hline $\begin{array}{l}\text { Standard } \\
\text { Deviation }\end{array}$ & 11,80 & 10,03 & 7,95 & 7,12 \\
\hline
\end{tabular}

Next, the findings from normality of the data. The normality test is to know whether the data is normally distributed or not. In this research, the writer used statistical computation by using SPSS version 21. By used the interpretation of Kolmogorov - Smirnov and Shapiro Wilk, the writer would conclude that the sample is in normal distribution or not. Further explanation on normality test was showed in Table 2 .

Table 2

Tests of Normality

\begin{tabular}{|l|l|r|r|r|r|r|c|}
\hline & \multicolumn{2}{|c|}{ Group } & \multicolumn{2}{|c|}{ Kolmogorov-Smirnov } & \multicolumn{3}{|c|}{ Shapiro-Wilk } \\
\cline { 3 - 8 } & & Statistic & df & Sig. & Statistic & \multicolumn{1}{c|}{ df } & \multicolumn{1}{c|}{ Sig. } \\
\hline \multirow{2}{*}{ Students_PretestScores } & Experimental Group & .215 & 17 & .036 & .905 & 17 & .082 \\
\cline { 2 - 8 } & Control Group & .189 & 17 & .110 & .924 & 17 & .170 \\
\hline \multirow{2}{*}{ Students_PosttestScores } & Experimental Group & .116 & 17 & $.200^{*}$ & .937 & 17 & .289 \\
\cline { 2 - 8 } & Control Group & .199 & 17 & .073 & .948 & 17 & .420 \\
\hline
\end{tabular}

*. This is a lower bound of the true significance.

a. Lilliefors Significance Correction

Based on the table in column of pre-test, the point of Shapiro-Wilk Test was 0,082 than the point of Asymp. Sig.(2-tailed) was 0,170 it was more than Alpha Point (0.05). So, it means that the data of pre-test score had a normal distribution.

Based on the table in column of post-test, the point of Shapiro-Wilk Test was 0,289 than the point of Asymp. Sig.(2-tailed) was 0,420 it was more than Alpha Point (0.05). So, it means that the data of post-test score had a normal distribution.

Homogeneity test is intended to show that two or more groups of the data samples come from population having same variance. The explanation of homogeneity test was seen in Table 3. 
Table 3

Test of Homogeneity of Variance

\begin{tabular}{|c|c|c|c|c|c|}
\hline & 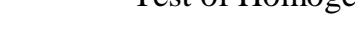 & Levene Statistic & df1 & df 2 & Sig. \\
\hline \multirow[t]{4}{*}{ Students_PretestScores } & Based on Mean & 1.069 & 1 & 32 & .309 \\
\hline & Based on Median & .428 & 1 & 32 & .518 \\
\hline & $\begin{array}{l}\text { Based on Median and } \\
\text { with adjusted df }\end{array}$ & .428 & 1 & 30.858 & .518 \\
\hline & Based on trimmed mean & 1.059 & 1 & 32 & .311 \\
\hline \multirow[t]{4}{*}{ Students_PosttestScores } & Based on Mean & .250 & 1 & 32 & .621 \\
\hline & Based on Median & .257 & 1 & 32 & .616 \\
\hline & $\begin{array}{l}\text { Based on Median and } \\
\text { with adjusted df }\end{array}$ & .257 & 1 & 30.994 & .616 \\
\hline & Based on trimmed mean & .237 & 1 & 32 & .630 \\
\hline
\end{tabular}

From table 3 is shown that the results of homogeneity of variances test Levene Statistics score was 0.309 for pretest. Since 0.309 was higher than alpha value level of 0.05 , it can be assumed that the variance of every data in pretest was homogenous. The test of homogeneity of variances show in the based on mean trimmed mean with significant was 0.311 for posttest. Since 0.311 was more than alpha value level of 0.05 , it can be assumed that the variance of every data in posttest was homogenous.

The paired t-test was done between pre-test and post-test of the students. The analyzing was be done by using SPSS version 21 . The analysis was be covered the paired t-test between pre-test and post-test. If the value of Sig. (2-tailed) < significance level $(\alpha=0,05)$ it means that the Ha is accepted (Discoverinf statistic using SPSS). The result of paired sample t-test can be shown in Table 4.

Table 4

Paired Samples Statistics

\begin{tabular}{lll|r|r|r} 
& & Mean & N & Std. Deviation & Std. Error Mean \\
\hline Pair 1 & Posttest_EG & 69.35 & 17 & 7.953 & 1.929 \\
\cline { 2 - 6 } & Pretest_EG & 59.29 & 17 & 11.804 & 2.863 \\
\hline Pair 2 & Posttest_CG & 51.88 & 17 & 7.123 & 1.728 \\
\cline { 2 - 6 } & Pretest_CG & 49.12 & 17 & 10.037 & 2.434 \\
\hline
\end{tabular}

Based on the table 4, the mean score of pre-test in experimental group was 59,29 and the mean score of post-test in control group was 49,35. It means that the score of posttest more than pre-test. Mean score of posttest in experimental group 69, 35 and posttest in control group 51, 88 .

Table 5

Paired Samples Correlations

\begin{tabular}{llr|r|r} 
& & N & Correlation & \multicolumn{1}{c}{ Sig. } \\
\hline Pair 1 & $\begin{array}{l}\text { Posttest_EG \& } \\
\text { Pretest_EG }\end{array}$ & 17 & .792 & .000 \\
\hline Pair 2 & $\begin{array}{l}\text { Posttest_CG \& } \\
\text { Pretest_CG }\end{array}$ & 17 & .584 & .014 \\
\hline
\end{tabular}

Based on table 5 the paired sample correlation between pre-test in experimental group and post-test in experimental group was 0,792 with the $\mathrm{N} 17$ students and the significance level was 0.000 and based on paired sample correlation between pretest in control group and posttest in control group was 0,584 with the N17 students and the significance was 0,014. 
Table 6

Paired Samples Test

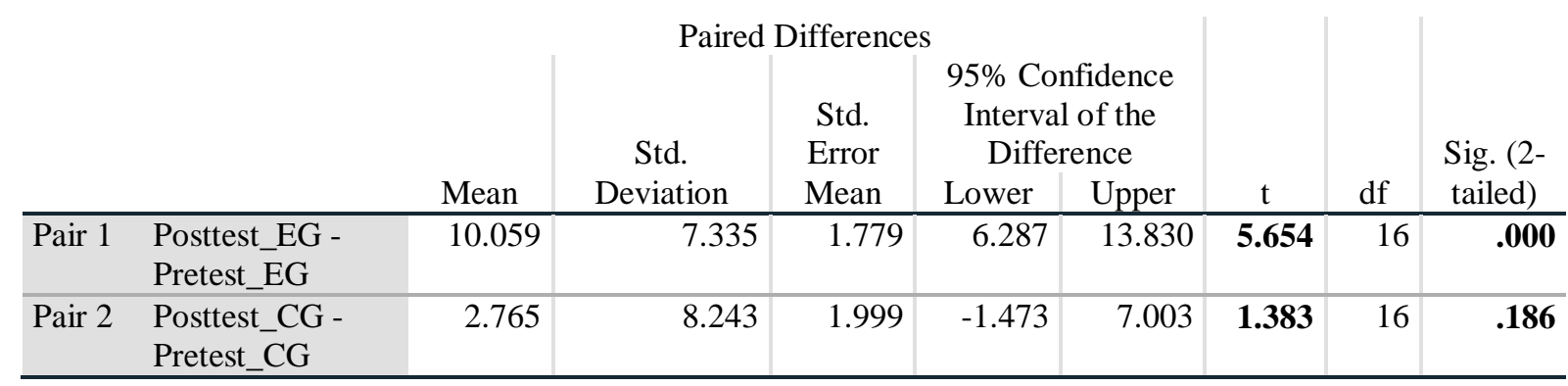

Based on table 6 on the Table Paired Samples Test, it was found that the mean score of pretest in experimental group and posttest in experimental group was 10,059 and the value of t-test 5,654 with degree of freedom $(\mathrm{df}=\mathrm{n}-1)=16$, and the value of Sig. (2-tailed) 0,000 less than the significance level $(\alpha=0.05)$ meanwhile, mean score of pretest in control group and posttest in control group was 2,765 and the value of t-test 1,383.

Based on result above,the researcher conclude that the null hypohesis (Ho) is rejected and the alternative hypothesis $(\mathrm{Ha})$ of this research was accepted. It means that there was a significant improvement of students speaking through task based learning In English foreign language at fourth semester of English Education study Program of Baturaja University.

\section{Questionnaire}

The questionnaire adopted from ismaili, $\mathrm{M}$ questionnaire of the students' perception On the $1^{\text {st }}$ Albania International conference on Education (AICE). The questionnaire have 7 items and the researcher use likert scale SA (Strongly Agree $)=4, \mathrm{~A}($ Agree $)=3, \mathrm{D}($ Disagree $)=2$ and SD (Strongly Disagree) $=1$. For further information of the result of this study, the closedended questionnaire that was administered toward the participant of this study showed that most of students strongly agree that task based learning help them enjoy in learning English and most of them agree with the item and there was no strong disagreement. For item no 1 "Task based learning helps the students enjoy learning English" 86,1\% strongly agreed and $13,89 \%$ agreed. For item no 2 I believe that I can learning English faster when I used it more often" $41,7 \%$ students strongly agree and 58, 33\% just agree. For item no 3 "Task activity give me more chances to practice English" 44, 4\% strongly agree, 44, 4\% agree and 11, 1\% disagree. For item no 4 "I am more motivated by the task which connect to the real life than situation from the book" $22,2 \%$ strongly agree, $69,44 \%$ agree and.8,3\% disagree. For item no 5 "Task involves a primary focus on meaning" $22,2 \%$ strongly agree, $38,9 \%$ agree and 38,9 disagree. For item no 6 "Task based learning advanced my critical thinking" 30, 6 strongly agree, $63,89 \%$ agree and 5,56\% disagree. For item no 7 "Using task based activities is a good way to improve English vocabulary" $75 \%$ strongly agree, $25 \%$ agree, and no disagree and strongly disagree. The data was presented in Table 7. 
Table 7

Students' perception on the use of Task Based Learning

\begin{tabular}{|c|c|c|c|c|}
\hline Item no & $\begin{array}{c}\text { SA (Strongly Agree) } \\
\mathbf{4}\end{array}$ & A (Agree) 3 & D (Disagree) 2 & $\begin{array}{c}\text { SD (strongly } \\
\text { Disagree) } \mathbf{1}\end{array}$ \\
\hline 1 & 31 & 5 & - & - \\
\hline 2 & 15 & 21 & - & - \\
\hline 3 & 16 & 16 & 4 & - \\
\hline 4 & 8 & 25 & 3 & \\
\hline 5 & 8 & 14 & 14 & - \\
\hline 6 & 11 & 23 & 2 & - \\
\hline 7 & 27 & 9 & - & \\
\hline
\end{tabular}

Most of the students give positive response on the use of task based learning. The students strongly agree that task based learning help them enjoy in learning English and they also mostly students agree that task based activities is a good way to improve English vocabulary.

The description of findings from the student's perception on the implementation of task based learning in improving speaking is shown in the figure 2.

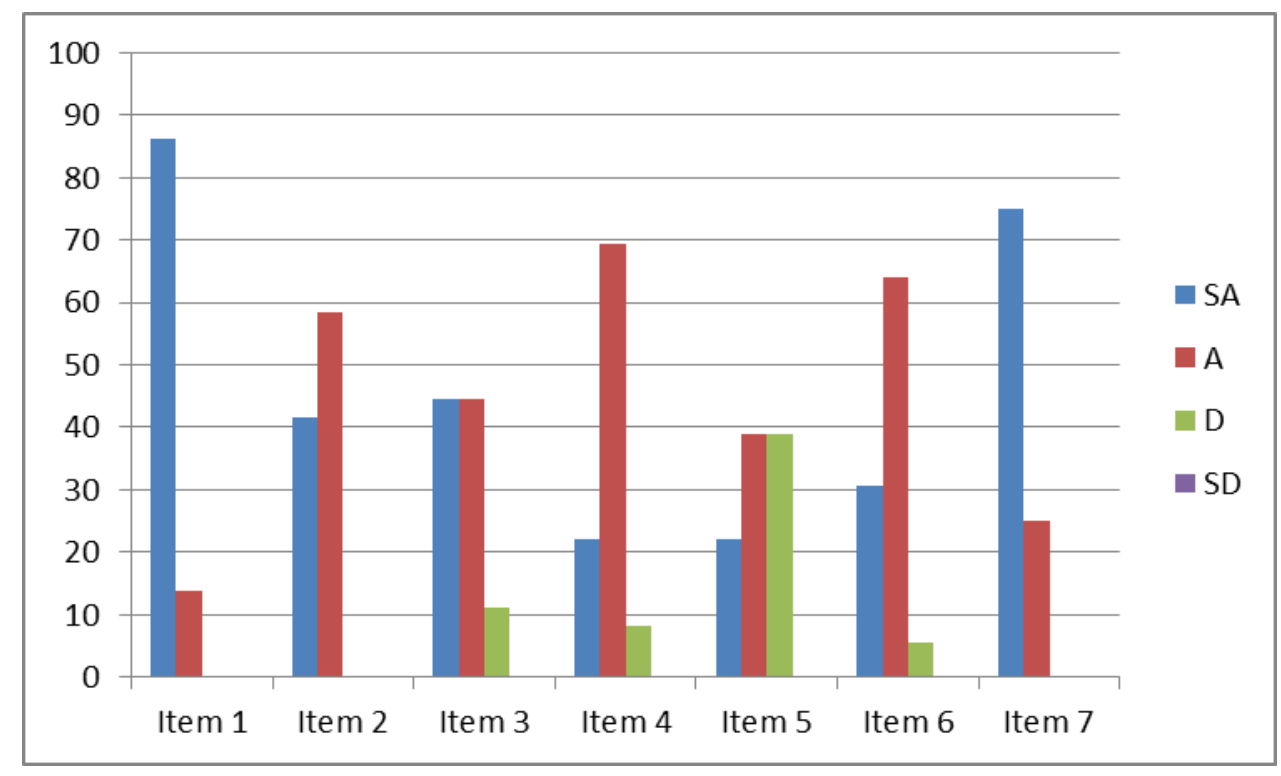

Figure 2. The Students' Perception on the use of Task Based Learning

Based on figure 2, the researcher can conclude that the students have positive perception on the use of task based learning in English Foreign Language Classroom. This fact encountered a good progress of speaking of the students.

\section{Discussions}

From the result of research finding above, the writer found that the students' mean score of post-test was high than the students' mean score in pre-test. Based on the finding, the researcher found that the mean score after calculating the pre-test score and post test score in experimental and control groups. The mean of pre- test score of experimental group was 59,29 and mean score of the control class was 49,88. After the treatments were conducted, the researcher administered the post-test. From the data calculation, the researcher found the different mean scores of the post-test in both groups. The experimental group got 69,11 while the control group got 51,88 In addition based on the calculation of paired sample statistic, it was shown that the value of sig (2-tailed) was more than $\alpha=0.05$, so alternative hypothesis (Ha) was acceptable and null hypothesis (Ho) was 
rejected. It means that task based learning was significantly improve the students' speaking skill at fourth semester of English education study program of Baturaja University. After the implementation of Task Based Learning in English Foreign Language at fourth semester of Baturaja University.

After the use of task based learning in teaching speaking the students' get better score and also better in speaking especially when perform English, they used various kinds of vocabulary and enjoy in learning speaking.

Ellis (2003) stated that Task-Based Language Teaching (TBLT) or Task Based Learning refers to teaching foreign language that seeks to engage learners in interactionally authentic language use by having them perform a series of tasks. This method had characteristic learners-centered and the task served as the means for achieving natural use of language. While there was relevant research was written by Azizah (2018) with title "The Effectiveness of Task-Based Language Teaching to Teach Speaking Skill At the Eighth Grade of MTS Muhammadiyah 3 Masaran in the Academic Year of 2018/2019, the result of her research showed that Task-Based Language Teaching is effective to teach speaking skill at the eighth grade of MTs Muhammadiyah 3 Masaran in the academic year of 2018/2019. From the result of Paired sample t-test, the writer could interpret the alternative hypothesis was accepted.

Based on the result of questionnaire, Most of the students give positive response on the use of task based learning. The students strongly agree that task based learning help them enjoy in learning English and they also mostly students agree that task based activities is a good way to improve English vocabulary. Hadi (2013) in his journal "perception of task based language teaching: A study of Iranian EFL Learners" mentioned that the implimentation of Task based language teaching or TBLT OR Task based learning implies that EFL Teachers can be positive in successfully applying TBLT in classess because the learners are willing to adapt themselves to this new approach of language teaching and the students revealed to a few negative views on TBLT implementation and through task based language teaching or TBLT or task based learning have many postive result, such as TBLT encourages learners' academic progress, improve students' interactive skill, encourages learners' inherent motivation, create collaborative learning experience and TBLT is suitable for small group work.

\section{CONCLUSION}

Based on the findings the researcher concludes that task based learning improve the students speaking skill. After the use of task based learning in teaching speaking the students' get better score and also better in speaking especially when perform English, they used various kinds of vocabulary and enjoy in learning speaking. And based on the result of questionnaire, Most of the students give positive response on the use of task based learning. The students strongly agree that task based learning help them enjoy in learning English and they also mostly students agree that task based activities is a good way to improve English vocabulary.

\section{REFERENCES}

Aleksandrzak, M. (2011). Problems and challenges in teaching and learning speaking at advanced level. Uniwersytet Im. Adama Mickiewicza W Poznaniu.

Azizah, F. (2018). The Effectiveness of Task-Based Language Teaching to teach Speaking Skill At the Eighth Grade of Mts Muhammadiyah 3 Masaran In The Academic Year of 2018/2019. Unpublished thesis. English Education Department Islamic Education and Teacher Training Faculty the State Islamic Institute of Surakarta. 
Brown, D. (2001). Teaching In Principle An Interactive Approach To Language Pedagogy. Second edition. New york. Pearson education.

Cheong, K., Hill, C., Chung, R., \& Leong, Y. (2015). Employing the 'unemployable': employer perceptions of Malaysian graduates. Studies in Higher Education, 5(10): 1-20. Flexible and engaging.

Cohen, L., Manion, L., \& Marrison, K. (2005). Research methods education. ( $5^{\text {th }}$ ed.). London: Routledge Falmer.

Derwing, T., \& Munro, M. (2005). Second Language Accent and Pronunciation Teaching: A Research-Based Approach. Alberta, Canada: TESOL Quarterly.

Ellis, R. (2003). Task-Based Language Teaching and Learning. Oxford: Oxford University Press.

Fraenkel, J., \& Wallen, N. (2009, August 10). How to design and evaluate research in education. America: Mc Graw-Hill, Inc. Retrieved August 18, 2020, from http://www.amazon.com/Design-EvaluateResearchEdu/dp/B008250ICQ.

Frost, R. (2019). Task based approach. British council, Turkey.

Hadi, A. (2013). perception of task based language teaching: A study of Iranian EFL Learners. Canadian center of Science of Education, 6(1).

Ismail, M. (2000). The effectiveness of the task-based learning in developing students' speaking skills in academic settings on the EFL classroom-A study conducted at South East European University (SEEU). 1st Albania International Conference on Education (AICE).

Kayi, H. (2006). Teaching Speaking: Activities to Promote Speaking in a Second Language. The Internet TESL Journal, 12(2).

Lemmolo, G. (2019, July 10). What is task based learning. Retrieved September 14, 2020, from https://www.ef.com/wwen/blog/teacherzone/what-is-task-based-learning/.

Malihah, N. (2010). The effectiveness of speaking instruction through task-Based language teaching. REGISTER, 3(1), 85-101.

Richards, J., \& Rodges T. (2001). Approach and method in language teaching a description an analysts. USA Cambridge University.

Willis J. (1996). Framework for Task-Based Learning. National Technical University of Ukraine "Igor Sikorsky Kyiv Polytechnic Institute". Retrieved September 15, 2020, from http://www.kamts1.kpi.ua/sites/default/files/files/pavlenko_corpora\%20in\%20a\%20nuts hell.pdf.

Zakime, A. (2018, January 19). What-is-Task-based-learning. Retrieved September 14, 2020, from https://www.whatiselt.com/single-post/2018/01/19/. 